\title{
Evaluation of Haematological Parameters of Catfish (Clarias gariepinus) Grown in Biofloc System using Three Different Carbon Sources
}

\author{
${ }^{1}$ Muhammad M. A. ${ }^{1, *}$ Babatunde T. A. (D), ${ }^{1}$ Babangida A. and ${ }^{2}$ Lawali A. A. \\ 1. *Department of Biology, Umaru Musa Ya'radua University, P.M.B. 2218, Katsina State, \\ Nigeria \\ 2 Department of Fisheries and Aquaculture, Usmanu Danfodiyo University, Sokoto, Nigeria \\ ${ }^{*}$ Corresponding author email: attaofeeq@gmail.com
}

\begin{abstract}
Biofloc Technology utilizes the addition of carbon sources to fish culture systems to allow the growth of bacteria, as well as aggregation of dead organic matter in the fish culture systems thereby permit continuous use of water. The use of biofloc for $C$. gariepinus culture has evaluated the growth, feed conversion and water quality. This experiment was conducted to evaluate the effects of carbon sources on the haematological parameters of catfish in the biofloc system. The biofloc system was set-up at the Biological garden of Umaru Musa Yar'adua University, Katsina. A total of two hundred (200) fingerlings catfish with an average weight of $8.45 \pm 1.6 \mathrm{~g}$ were randomly distributed in eight (8) plastic tanks at stocking densities $0 \mathrm{~g} / \mathrm{g} / \mathrm{m}^{3}$. Three carbon sources namely; corn flour, rice bran, and sorghum flour were used to support the flocculation and growth of catfish in the system. The fishes were fed uniformly with a commercial diet ad-libitum. After six weeks rearing period, the survival of fish in all treatments was not significantly different $(p<0.005)$; control $(94 \%)$; corn-flour $(90 \%)$, sorghum flour $(98 \%)$ and rice bran $(96 \%)$. Total weight gain was significantly higher $(p<0.005)$ in corn-flour biofloc treatment. The blood sample collected for haematological analysis showed a significant difference $(p<0.05)$ in the mean blood parameters with respect to park cell volume (PCV), white blood cell (WBC), and haemoglobin $(\mathrm{mg} / \mathrm{l})$ values. The PCV of the rice bran treatment $(18.00 \%)$ was significantly lower $(p<0.05)$ compared with other treatments. White blood cell $(W B C)$ was significantly higher in rice bran treatment $(p<0.05)$. The result indicated that corn-flour and sorghum could be used as the carbon source in the biofloc system with no effect on haematological parameters.

Keywords: Biofloc, Carbon sources, Catfish, Hematology.
\end{abstract}

\section{INTRODUCTION}

Biofloc system aimed to improve production efficiency and mitigate the environmental impacts of waste in aquaculture. In places where there is water scarcity, aquaculture production systems like biofloc and aquaponics would be desirable for cost-effective production. Wastewater management is one of the few challenges associated with aquaculture production and a biofloc system is one of the eco-friendly alternatives (Mahanand et al., 2019). The Biofloc Technology (BFT) allows the growth of bacteria and plankton, as well as aggregation of dead organic matter in the fish holding systems (Reis et al., 2012). The natural production of this organism is achieved by the addition of carbon sources or fertilizers to the fish rearing system (Crab et al., 2012) which allows the conversion of nitrogenous waste generated by the cultivated fish more especially ammonium into bacterial biomass in the culture solution (Himaja et al., 2016).
The availability of these bacteria boost the production of plankton biomass in the system, thereby serving as a food supplement for fish, hence increased production is achieved. Production of microbial protein takes place by the addition of carbohydrates to the pond, and therefore bacterial growth and nitrogen uptake are stimulated through it (Avnimelech, 1999). Research on biofloc application on Clarias gariepinus culture has evaluated the growth, feed conversion and water quality (Akeem et al., 2017). The BFT study on C. gariepinus culture with different carbon sources on fish physiology and haematological parameters is very limited. Therefore, it is important to conduct a study that examines the physiological condition and the haematological parameters of catfish under different carbon sources. Haematological parameters are key indicators for the evaluation of the suitability of using different carbon sources of fish (Docan et al., 2011). 


\section{MATERIALS AND METHODS}

Set up of the biofloc system

The present study was carried out between June and August, 2020 at the biological garden of the Department of Biology, Umaru Musa Yar'adua University, Katsina. Catfish (Clarias garapinus) fingerlings were obtained from a hatchery department of the National Biotechnology Development Agency (NABDA), Katsina and were adapted to the experimental conditions for two weeks. After the acclimation period, 200 African catfish fingerlings with an average body weight of $8.45 \pm 1.6 \mathrm{~g}$ were Estimation of growth performance

The following growth parameters were determined at the end of six weeks rearing period:

- Survival (\%) $=\frac{\text { Number of harvested fish }}{\text { number of stocked fish }} \times 100$

- Weight gain (\%) $=\frac{\text { Mean final weight }- \text { mean initial weight }}{\text { mean initial weight }} \times 100$

- Specific growth rate $(\% /$ day $)=\frac{\ln (\text { Final weight }- \text { initial weight })}{\text { number of days }} \times 100$
Determination of blood parameters

At the end of the experiment, fish were randomly picked from each treatment, and the blood samples were collected by using a syringe and pooled into EDTA containers. Blood filled heparinized micro haematocrit capillary tubes were centrifuged at 12000 for 5minutes using a microhaematocrit centrifuge and haematocrit values were read directly. The red blood cell and white blood cell counts were determined using a method devised by Yokayama (1947). Haemoglobin $(\mathrm{Hb})$ was determined using a spectrophotometer at 540nm using the Drabkin"s solution. Mean Corpuscular Volume (MCV), Mean Corpuscular Haemoglobin $(\mathrm{MCH})$ and Mean Corpuscular Haemoglobin Concentration $(\mathrm{MCHC})$ were calculated from values of haemoglobin, haematocrit and total red blood count using the formula by Anderson and Klontz (1965).

$M C V=P C V / R B C \times 10$

$\mathrm{MCH}=\mathrm{Hb}(\mathrm{g} / \mathrm{dl}) / \mathrm{RBC} \times 10$

$\mathrm{MCHC}=\mathrm{Hb}(\mathrm{g} / \mathrm{dl}) / \mathrm{PCV} \times 100$ randomly distributed in eight (8) outdoor 500 litre plastic tanks at an initial stocking density of $1 \mathrm{~g} / \mathrm{m}^{3}$. The tanks were connected to aerators so that an air current is created in the tank. The fish were fed $5 \%$ body weight twice daily (9:00 $\mathrm{h}$ and 17:00 h). The carbon-nitrogen $(\mathrm{C}: \mathrm{N})$ ratio in the feed as specified by the manufacturer was adjusted to 15:1 recommended in biofloc (Avnimelech, 1999; Perez-Fuentes et al., 2016)) through the addition of carbon sources. The three different carbon sources viz: corn flour, mill rice bran, and sorghum flour were used in each treatment in duplicate.

\section{Statistical analysis}

All data were analyzed using IBM SPSS statistics version 21. The data was presented in mean \pm SD. ANOVA was used to test for the significant difference in the blood parameters among the treatment. The differences among the means were set to be significant at $p<$ 0.05 .

\section{RESULTS}

\section{Survival and growth}

The use of corn-flour, rice bran, and sorghum flour as carbon sources in this experiment supported the growth of catfish in biofloc. The survival of fish in all treatments did not deviate from that of a control group (94\%); corn treatment (90\%), sorghum (98\%) and rice bran (96\%) (Table 1). Total weight gain was significantly higher $(p<0.005)$ in corn treatments compared to control. Specific growth rate (SGR), showed significantly higher values among the treatments $(p<0.05)$ compared to those of the control (Table 1)

Table 1. Survival and growth rate of catfish in biofloc system using three different carbon sources

\begin{tabular}{|c|c|c|c|c|}
\hline \multirow[b]{2}{*}{ Parameters } & \multicolumn{3}{|c|}{ Carbon Sources } & \multirow[b]{2}{*}{ Control } \\
\hline & Corn & Rice bran & Sorghum & \\
\hline $\begin{array}{l}\text { Weight Gain }(\mathrm{g}) \\
\text { Percentage survival }\end{array}$ & $\begin{array}{l}312.55 \\
90\end{array}$ & $\begin{array}{l}265.30 \\
96\end{array}$ & $\begin{array}{l}308.10 \\
98\end{array}$ & $\begin{array}{l}295.35 \\
94\end{array}$ \\
\hline Specific Growth Rate(\%/day ) & 0.059 & 0.056 & 0.055 & 0.053 \\
\hline
\end{tabular}




\section{Blood Parameters}

The haematological parameters of catfish reared in biofloc under three different carbon sources were presented in Table 2. Catfish in rice bran biofloc was observed to have significantly lower PVC (18.20\%) among all the treatments while the control treatment group has the highest PVC of $23.00 \%$.

Table 2. Hematological parameters of catfish reared in biofloc under three different carbon sources

\begin{tabular}{lllll}
\hline Parameters & Corn & Rice bran & Sorghum & Control \\
\hline PCV $(\%)$ & $22.00^{\mathrm{a}}$ & $18.20^{\mathrm{b}}$ & $22.75^{\mathrm{a}}$ & $23.00^{\mathrm{a}}$ \\
WBC $\left(\times 10^{3} \mathrm{~mm}^{-3}\right)$ & $31.20^{\mathrm{a}}$ & $33.50^{\mathrm{b}}$ & $30.15^{\mathrm{a}}$ & $27.40^{\mathrm{c}}$ \\
$\mathrm{RBC}\left(\times 10^{6} \mathrm{~mm}^{-3}\right)$ & $2.50^{\mathrm{a}}$ & $2.10^{\mathrm{b}}$ & $2.35^{\mathrm{c}}$ & $2.90^{\mathrm{c}}$ \\
$\mathrm{Hb}(\mathrm{g} / \mathrm{dl})$ & 11.50 & 8.00 & 9.70 & 12.15 \\
MCV $(\mathrm{fl})$ & 88.5 & 87.57 & 97.55 & 79.70 \\
MCHC $(\%)$ & 53.25 & 44.90 & 43.15 & 53.26 \\
MCH $(\mathrm{pg})$ & 46.57 & 38.85 & 42.15 & 42.55 \\
\hline
\end{tabular}

\section{DISCUSSION}

Haematological parameters reflect the status and condition of the blood available for an animal for live activities (Adorian et al., 2019). The significant reduction in the PCV in rice bran treatment could be an indication of an anaemic condition resulting from the destruction of erythrocytes. Rice bran is a lignified organic matter, which may form flocculants that cannot be easily digested by fish (Madeira et al., 2017). The BFT may be considered a sustainable method to maintain water quality within an acceptable range for fish (Boyd and Zimmerman, 2000) and healthy physiological conditions as shown in the current study. The accumulation of high level of toxic ammonia and nitrate resulting to the low survival rates or decreased growth can be prevented and therefore, BFT make it possible to increase survival level and a potential additional natural food resource is provided, more specifically in the form of flocs (Mallasen and Valenti, 2006; Asaduzzaman et al., 2008). The present study also supports these as treatment groups had a high survival rate compared with a control that did not receive any addition of carbon. The

\section{REFERENCES}

Adorian, T. J., Jamali, H., Farsani, H. G., Darvishi, P., Hasanpour, S., Bagheri, T. and

Roozbehfar, R. (2019). Effects of probiotic bacteria Bacillus on growth performance, digestive enzyme activity, and haematological parameters of Asian sea bass, Lates calcarifer (Bloch). Probiotics and antimicrobial proteins, 11(1), 248-255.

Akeem, B., Nicholas, R., Mahdi, E., Murni, K., Ikhsan, N., Mohd, S. K. and Julie, E. (2017). Different carbon sources affect

UMYU Journal of Microbiology Research ability to ingest and digest the biofloc determine the nutritional value of the biofloc. Feed digestibility is generally less in the larval stages while survival is measured in the postlarval stage (Das et al., 2007). The rice bran and sorghum biofloc showed lesser digestibility. Therefore, these biofloc fed animals showed a low survival when compared to corn treatment. The values of blood parameters obtained for catfish in the current finding were within the range reported for catfish under feeding trials using soya beans (George et al., 2007).

\section{CONCLUSION}

The result of this research showed that cornflour and sorghum could be used as the carbon source in the biofloc system for $C$. gariepinus with no effect on haematological parameters. The lower parked cell volume and elevated white blood count in $C$. gariepinus in rice bran treatment indicated a lower performance of rice-bran as carbon source in biofloc system. Further research to degrade the lignin in rice bran through fermentation could boost its carbon release for use in biofloc technology.

biofloc volume, water quality and the survival and physiology of African catfish Clarias gariepinus fingerlings reared in an intensive biofloc technology system. Fish Sci. 83:1037-1048.

Anderson, D. and Klontz, G. W. (1965). Basic Haematology for the fish culturist. Ann. Northw. Fish Cult. Conf. 16: 38- 41.

Asaduzzaman, M., Wahab, M. A., Verdegem, M. C. J., Huque, S., Salam, M. A. and Azim, M. E. (2008). C/N ratio control and substrate addition for periphyton development jointly enhance 
freshwater prawn Macrobrachium rosenbergii production in ponds. Aquaculture, 280(1-4): 117-123.

Avnimelech, Y. (1999) Carbon/nitrogen ratio as a control element in aquaculture systems. Aquaculture 176:227-235

Boyd, C. and Zimmerman, S. (2000). Grow-Out Systems-Water Quality and Soil Management. In: Freshwater Prawn Culture-The Farming of Macrobrachium rosenbergii, New, M.B. and W.C. Valenti (Ed.). Blackwell Science, Oxford, UK., pp: 221-238.

Crab, R., Defoirdt, T., Bossier, P. and Verstraete, W. (2012). Biofloc technology in aquaculture: beneficial effects and future challenges. Aquaculture, 356: 351-356.

Das, S. K., Tiwari, V. K., Venkateshwarlu, G., Reddy, A. K., Parhi, J., Sharma, P. and Chettri, J. K. (2007). Growth, survival and fatty acid composition of Macrobrachium rosenbergii (de Man, 1879) -post-larvae fed HUFA-enriched Moina macroura. Aquaculture, 269: 464-475.

Docan, A., Dediu, L. and Cristea, V. (2011). Effect of feeding with different dietary protein levels on haematological indices of juvenile Siberian sturgeon, Acipenser baeri reared under recirculating systems condition. $A A C L$ Bioflux 4(2):180-186.

George, F.O.A., S.O. Obasa and S.O. Otubusin, 2007. Growth response and carcass quality of

African Catfish, Clarias gariepinus (Burchell, 1822) fed multi-enzyme-supplemented soybean meal diets. J. Applied Trop. Agric., 12: 51-59.
Himaja, P. H. S. and Rajagopalasamy, C. B. T. (2016). Review on biofloc meal as an alternative ingredient in aquaculture feeds. Journal of Aquaculture in the Tropics, 31(3/4), 199.

Mahanand, S. S. and Pramod K. P. (2019). Application of biofloc technology for sustainable

aquaculture development." Advances in Fish Research 3: 263-274.

Madeira Jr, J. V., Contesini, F. J., Calzado, F., Rubio, M. V., Zubieta, M. P., Lopes, D. B., and

de Melo, R. R. (2017). Agro-industrial residues and microbial enzymes: an overview on the eco-friendly bioconversion into high value-added products. Biotechnology of microbial enzymes, 475-511.

Mallasen, M. and Valenti, W. C. (2006). Effect of nitrite on larval development of giant river prawn Macrobrachium rosenbergii. Aquaculture, 261: 12921298.

Reis, W. G., Wasielesky Jr, W., Abreu, P. C., Brandão, H. and Krummenauer, D. (2019).

Rearing of the Pacific white shrimp Litopenaeus vannamei (Boone, 1931) in BFT system with different photoperiods: effects on the microbial community, water quality and zootechnical performance. Aquaculture, 508, 19-29. 